\title{
A prosztatarák kezelésében alkalmazott besugárzási technikák vizelési képességre gyakorolt korai hatása
}

\author{
Nahaji István dr. ${ }^{2}$ - Fröhlich Georgina dr. ${ }^{2,4}$ - Mavrogenis Stelios dr. ${ }^{3}$ \\ Szabó János Ferenc dr. ${ }^{3}$ - Polgár Csaba dr. ${ }^{1,2}$ - Ágoston Péter dr. ${ }^{1,2}$ \\ ${ }^{1}$ Semmelweis Egyetem, Általános Orvostudományi Kar, Onkológiai Tanszék, Budapest \\ ${ }^{2}$ Országos Onkológiai Intézet, Sugárterápiás Központ, Budapest \\ ${ }^{3}$ Országos Onkológiai Intézet, Daganatsebészeti Központ, Uro-onkológiai Daganatsebészeti Részleg, Budapest \\ ${ }^{4}$ Eötvös Loránd Tudományegyetem, Természettudományi Kar, Budapest
}

Bevezetés: A prosztatarák kezelésében jelentős szerepet kapnak a különböző sugárterápiás eljárások. Ennek ellenére a vizelési képességre gyakorolt, rövid és hosszú távú mellékhatásaikat objektív vizsgálómódszerrel igen kevés tanulmányban vizsgálták.

Célkitüzés: Arra a kérdésre kerestük a választ, hogy hogyan változik a korai vizelési képesség a különböző sugárterápiás eljárások során.

Módszerek: A vizsgálatunkban meghatározott protokoll szerint a kezelés előtt minden bevont beteggel IPSS-t (nemzetközi prosztatatünet-értékelő lap) töltettünk ki, illetve uroflow (vizeletáramlási) vizsgálatot végeztünk, suprapubicus ultrahanggal meghatározott mictiós residuum méréssel kiegészítve. A sugárkezelés befejezésétől számított 4-6 héten belül ismételten elvégeztük ezeket a vizsgálatokat, melyekbe összesen 26 beteget vontunk be. A kezelési modalitások szerint 6 , kis dózisteljesítményú (low-dose rate; LDR) brachytherapiában, 5, nagy dózisteljesítményú (high-dose rate; HDR) brachytherapiában, 12, Cyberknife (CK) készüléken extrém hipofrakcionált sugárkezelésben és 3, lineáris gyorsítón (LINAC) mérsékelten hipofrakcionált sugárkezelésben részesített prosztatarákos beteget választottunk be. A kezelések hasonlósága miatt az LDR-és a HDR-csoportot együttesen brachytherapiás csoportként (BTCS), a CK- és a LINAC-csoportot teleterápiás csoportként (TTCS) vizsgáltuk.

Eredmények: A BTCS betegeinél az IPSS- és az uroflow paraméterek korai romlása (IPSS irritatív panaszok: $\mathrm{p}=$ 0,003, IPSS obstruktív panaszok: $\mathrm{p}=0,01 \mathrm{l}$, maximális áramlás: $\mathrm{p}=0,003$, átlagos áramlás: $\mathrm{p}=0,006$ ) szignifikánsnak bizonyult, a TTCS-ban mindösszesen az IPSS irritatív tünetekben volt kimutatható eltérés $(\mathrm{p}=0,011)$.

Következtetés: A sugárterápiás modalitás kiválasztása előtt javasolható az uroflow és az IPSS-vizsgálat elvégzése. Eredményeink alapján azoknál a betegeknél, akiknél a kezelés előtt középsúlyos vagy súlyos dysuriás vizelési panaszok állnak fenn, a brachytherapia helyett teleterápiás módszerek alkalmazását javasoljuk, amelyek kevésbé rontják a betegek korai vizeletürítési képességét.

Orv Hetil. 2021; 162(33): 1328-1334.

Kulcsszavak: prosztatarák, sugárterápia, uroflow, IPSS, mellékhatás

\section{Early effects of different irradiation techniques used in the treatment of prostate cancer on urination}

Introduction: Various radiotherapy procedures are applied in the treatment of prostate cancer. Nevertheless, their early and late side effects measured by uroflow and residual volume measurements have not been studied extensively. Objective: We investigated by objective methods the early changes of urination ability after different radiotherapy procedures.

Methods: According to the protocol defined in our study, all patients had their IPSS (international prostate symptom score) determined, as well as their uroflow examinations and measurements of their residual urine via suprapubic ultrasound, carried out before treatment. These tests were then repeated at 4-6 weeks after the end of their radiotherapy. A total of 26 patients were included in the study. 6 patients were treated with low-dose rate (LDR) brachytherapy and 5 patients with high-dose rate (HDR) brachytherapy, 12 patients with Cyberknife (CK) using extreme hypofractionation and 3 patients with moderately hypofractionated radiotherapy with a linear accelerator (LINAC). Due to the similarity of the treatments, the LDR and HDR groups together were also studied as brachytherapy group and the CK and LINAC patients as teletherapy group. 
Results: We found that the early deterioration of IPSS and uroflow parameters after brachytherapy were significant (IPSS irritative symptoms: $\mathrm{p}=0.003$, IPSS obstructive symptoms: $\mathrm{p}=0.011$, maximum flow: $\mathrm{p}=0.003$, mean flow: $\mathrm{p}=0.006)$, while in teletherapy only the IPSS irritative symptoms worsened significantly $(\mathrm{p}=0.011)$.

Conclusion: Based on our results, we suggest to perform uroflow examination and IPSS test before selecting therapeutic modality for patients with prostate cancer. In patients with moderate or severe urinary complaints before the treatment, we recommend to use teletherapy rather than brachytherapy.

Keywords: prostate cancer, radiotherapy, uroflow, IPSS, side effect

Nahaji I, Fröhlich G, Mavrogenis S, Szabó JF, Polgár Cs, Ágoston P. [Early effects of different irradiation techniques used in the treatment of prostate cancer on urination]. Orv Hetil. 2021; 162(33): 1328-1334.

(Beérkezett: 2020. december 23.; elfogadva: 2021. február 23.)

\section{Rövidítések}

BTCS = brachytherapiás csoport; CK = Cyberknife; Gy = gray (mértékegység; bármely anyagban elnyelődött ionizáló sugárzás dózisát adja meg); HDR = (high-dose rate) nagy dózisteljesítményü; IGRT = (image-guided radiotherapy) képvezérelt sugárkezelés; IMRT = (intensity-modulated radiotherapy) intenzitásmodulált sugárkezelés; IPSS $=($ international prostate symptom score) nemzetközi prosztatatünet-értékelő lap; LDR $=($ low-dose rate $)$ kis dózisteljesítményü; LINAC $=($ linear accelerator) lineáris gyorsító; NSAID = (nonsteroidal anti-inflammatory drug) nemszteroid gyulladásgátló gyógyszer; Qavr $=($ average flow rate $)$ átlagos áramlási sebesség; $\mathrm{Qmax}=(\operatorname{maxi}-$ mum flow rate) maximális áramlási sebesség; TTCS = teleterápiás csoport; $\mathrm{V}=$ (volume) térfogat

A férfiak körében világszinten és hazai viszonylatban is az egyik leggyakrabban előforduló rosszindulatú megbetegedés a prosztatarák [1, 2]. Magyarországon évente 4500-5000 esetben diagnosztizálják, javarészt korai, szervre lokalizált stádiumban [2, 3]. A szervre lokalizált prosztatarák kezelésében kétféle definitív kezelés választható. Az egyik a radikális prostatectomia, a másik a sugárterápia, amely a nemzetközi kezelési irányelvek szerint a mütéti kezelés teljes értékű alternatívája [4]. Sugárterápia végezhető szövetközi brachytherapiával, illetve teleterápiás módszerekkel is.

A prosztata teleterápiás kezelése során az általunk képalkotók segítségével kialakított céltérfogatot egy külső sugárforrás segítségével látjuk el. A modern képalkotó eljárásoknak és a fejlett, besugárzást végző készülékeknek köszönhetően nagy pontossággal adható le a megfelelő sugárdózis. A kezelést intenzitásmodulált sugárkezeléssel (IMRT) végezzük, melynek lényege, hogy a céltérfogatot körülölelő dóziseloszlást változó dózisintenzitású mezőkkel hozzuk létre. A kezelés pontos kivitelezéséhez képvezérelt sugárkezelést (IGRT) alkalmazunk. Az Országos Onkológiai Intézetben mérsékelt hipofrakcionált (napi 2,5 Gy 28 alkalommal, egymást követő munkanapokon) és extrém hipofrakcionált (másnaponta adott 8 Gy 5 alkalommal) kezelési protokoll van használatban $[5,6]$.

Teleterápiát végezhetünk a hagyományos, széles körben elterjedt lineáris gyorsítóval (LINAC), illetve robot- karos Cyberknife (CK) készülékkel. A CK előnyösebb a LINAC-hoz képest, mert képes a kezelés alatti esetleges betegelmozdulást, szervelmozdulást követni (tumor tracking) és az ebből adódó beállítási hibákat javítani, így nagyobb pontosságot tudunk elérni vele, illetve a fennálló kezelési séma alapján a kezelés ideje is jóval rövidebb.

A brachytherapia lényege, hogy a sugárforrást közvetlenül a tumor vagy tumorágy közelébe juttatjuk be. A prosztata brachytherapiája során kétféle kezelési módszert használunk. Az egyik a permanens 'seed 'implantációs, kis dózisteljesítményü (low-dose rate, LDR) terápia, a másik a nagy dózisteljesítményú (high-dose rate, HDR) brachytherapia.

LDR kezelés során $\mathrm{I}_{125}$-tartalmú sugárforrásokat (50$80 \mathrm{db}$ ) implantálunk gáton keresztül a prosztata állományába, amelyek bent maradnak a beteg élete végéig. A terápiás dózis leadása a sugárforrások beültetése után folyamatosan történik. Egy hónap alatt a teljes dózis kb. 30\%-a, két hónap alatt kb. 50\%-a, míg egy év alatt nagyjából a 98\%-a kerül leadásra [7]. Előnye, hogy a kezelés mindössze kétnapos kórházi bennfekvést igényel, a radikális mütéthez képest kevesebb az impotencia és az incontinentia, míg a külső besugárzáshoz képest kisebb a végbélgyulladás kialakulásának esélye $[8,9]$.

HDR brachytherapia során - a gáton át inaktív túk ultrahangos támogatással végzett beültetését követően a távvezérelt, ún. 'afterloading' készülékből egy motor segítségével mozgatott és összekötő tubusokon keresztül a túkbe juttatott léptetett sugárforrás $\left(\operatorname{Ir}_{192}\right)$ megállási idejének és helyzetének meghatározásával a prosztata valós geometriai helyzetéhez alakítható a dóziseloszlás. A tưk valódi helyzetének megfelelően a dózisterv módosítható (valós idejű besugárzástervezés), így nem kell számolni a túk behelyezését követően a prosztata deformálódásával, a sugárforrások elmozdulásával, vándorlásával és a dózislefedettség későbbi csökkenésével sem.

A sugárterápia hatékonysága nagyjából megegyezik a mútéti megoldáséval, a mellékhatások előfordulásában viszont különbségek mutatkoznak [9, 10]. Sugárterápiás kezelést követően megkülönböztetünk sugárzás okozta korai és késői mellékhatásokat.

A korai mellékhatások a kezelést követő 3 hónapon belül jelentkeznek. A leggyakoribb korai mellékhatás a 


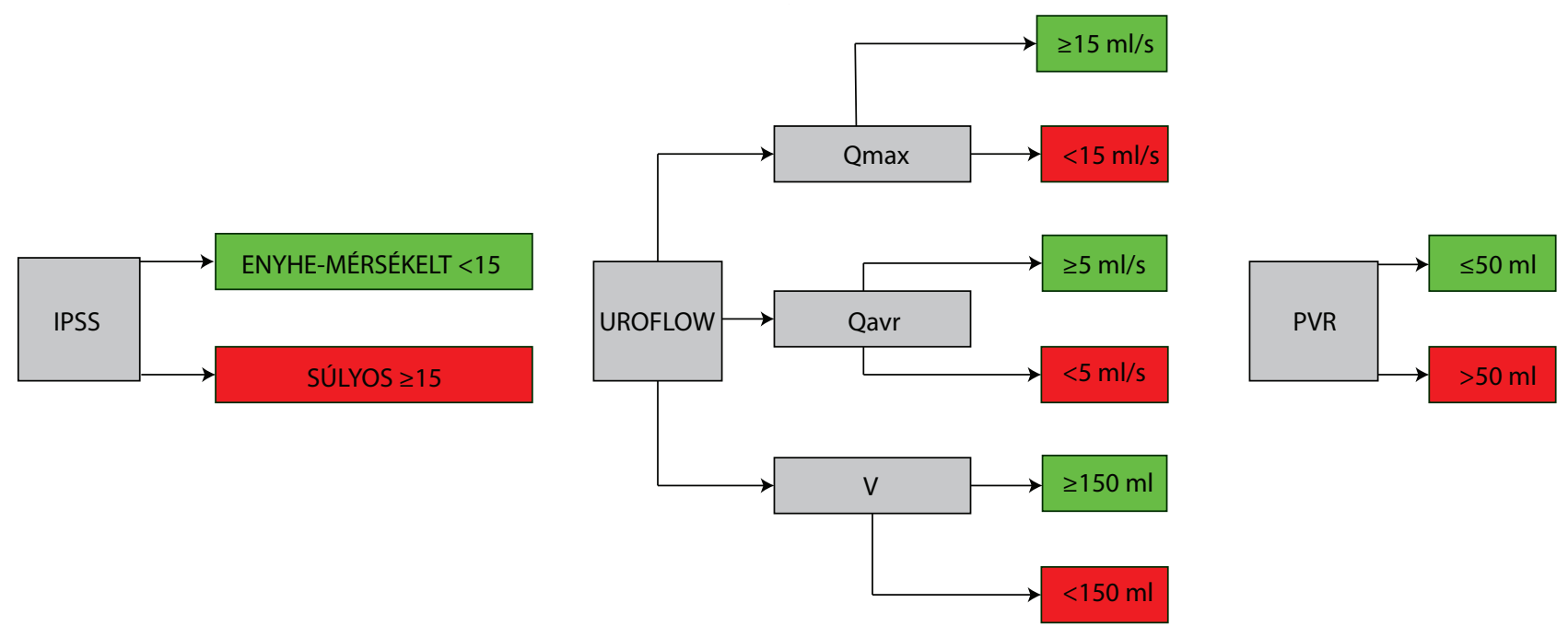

1. ábra $\begin{aligned} & \text { A különböző vizsgálati paraméterek és az ezeken belül meghatározott, károsodott vizelési képességet jelző (piros) és a megfelelő vizelési képességet } \\ & \text { jelző (zöld) tartományokhoz tartozó határértékek }\end{aligned}$
$\begin{aligned} & \text { IPSS = nemzetközi prosztatatünet-értékelő lap; PVR = vizelés után a hólyagban maradt vizelet térfogata; Qavr = átlagos áramlás; Qmax = maximális } \\ & \text { áramlás; } \mathrm{V}=\text { térfogat }\end{aligned}$

végbélgyulladás, mely hasmenést, akár véres székelést okozhat, és a cystoprostatitis, mely gyakori vizelési ingerrel, szúró, csípő jellegú vizeléssel jár. Az utóbbi az esetek kb. harmadában jelentkezik [11].

A késői mellékhatások a sugárkezelést követő 1-3 év múlva léphetnek fel. Késői mellékhatásként jelentkezhet a vizelési képesség romlása, incontinentia, a húgycső hegesedés okozta szúkülete, vérző proctitis, cystitis, illetve erectilis diszfunkció [12].

A vizsgálat célja, hogy megismerjük és kvantitatívan összevessük a brachytherapia és a teleterápia különböző formái által okozott korai urológiai mellékhatásokat uroflowmetriás (vizeletáramlás-mérő) eszköz, ultrahangos residuummeghatározás és IPSS-kérdőív segítségével.

\section{Beteg és módszer}

A vizsgálatba azokat a betegeket vontuk be, akik megfeleltek a következő feltételeknek: kis, közepes és nagy kockázatú, klinikailag szervre lokalizált prosztatarák miatt definitív sugárkezelést kaptak, korábban külső besugárzás nem érte a kismedencét, a biopszia óta eltelt legalább 8 hét. Nem volt az anamnézisben semmilyen ismert húgyhólyag-, húgycső- és péniszfejlődési, anatómiai rendellenesség, neurogen incontinentiájuk kizárható, tudatuk ép volt, a kérdőívet ki tudták tölteni, a vizsgálatba beleegyeztek.

A vizsgálatba $6, \mathrm{LDR}$ brachytherapiában, 5, HDR brachytherapiában, 12, CK készüléken extrém hipofrakcionált sugárkezelésben és 3, LINAC készüléken mérsékelt hipofrakcionált kezelésben részesített beteg került bevonásra, akik kezelése 2019. 07. 18. és 2019. 11. 21. között zajlott.

A vizsgálat egy beteg esetében kétszeri találkozással történt. Az első vizsgálat a kezelés megkezdése előtt, míg a második a terápia befejezését követő 4-6. héten zajlott.

A kivizsgálás során a betegek a betegtájékoztató elolvasása és átbeszélése után írásban hozzájárultak a vizsgálathoz, amelyben önkéntes alapon vettek részt. Ezek után IPSS-tesztet töltöttek ki, miközben bőséges folyadékfogyasztással a vizelési inger eléréséig hidratálták magukat.

Az IPSS-teszt 7 kérdésből áll, kérdésenként minimum 0 , maximum 5 pontot lehet kapni. A kérdések egyik része a vizeletürítésre (1., 3., 5., 6. kérdés), másik része a vizelettárolásra (2., 4., 7. kérdés) vonatkozik. 0-7 pont esetében enyhe, 8-19 pontnál közepes, míg 20 pont felett súlyos tünetekről beszélünk. Vizsgálatunkban a 0-14 pontos választ adókat - a panasz irritatív vagy obstruktív jellegétől függetlenül - enyhe-mérsékelt tüneteseknek, a 15-35 pontos választ adókat súlyos tüneteseknek különítettük el (1. ábra).

Amikor a bőséges folyadékfogyasztás hatására a betegeknek erős vizelési ingerük jelentkezett, elvégeztük az uroflowmetriás vizsgálatot, melynek során a beteg egy műanyag tölcsérbe üríti vizeletét, miközben a gép adatokat gyưjit az ürített térfogatról (V, ml), a maximális áramlási sebességről ( $\mathrm{Qmax}, \mathrm{ml} / \mathrm{s})$, az átlagos áramlási sebességről (Qavr, $\mathrm{ml} / \mathrm{s}$ ) és az ürítés időtartamáról (s) (2. ábra). Közvetlenül a vizelés után a beteg hólyagján suprapubicusan ultrahangkészülékkel mictiós residuum vizsgálatot végeztünk.

Az uroflow mérést akkor tekintettük értékelhetőnek, ha az ürített vizelet mennyisége elérte a 150 ml-t. 150 $\mathrm{ml}$ alatti mérési eredmény esetén kikérdeztük a beteget a vizelési képességéről, illetve megnéztük az IPSS értékeit. Amennyiben azt tapasztaltuk, hogy a beteg súlyos tünetes ( 15 feletti pontszám), abban az esetben nem kezdeményeztünk új vizsgálatot, hiszen nem emberi tényező 

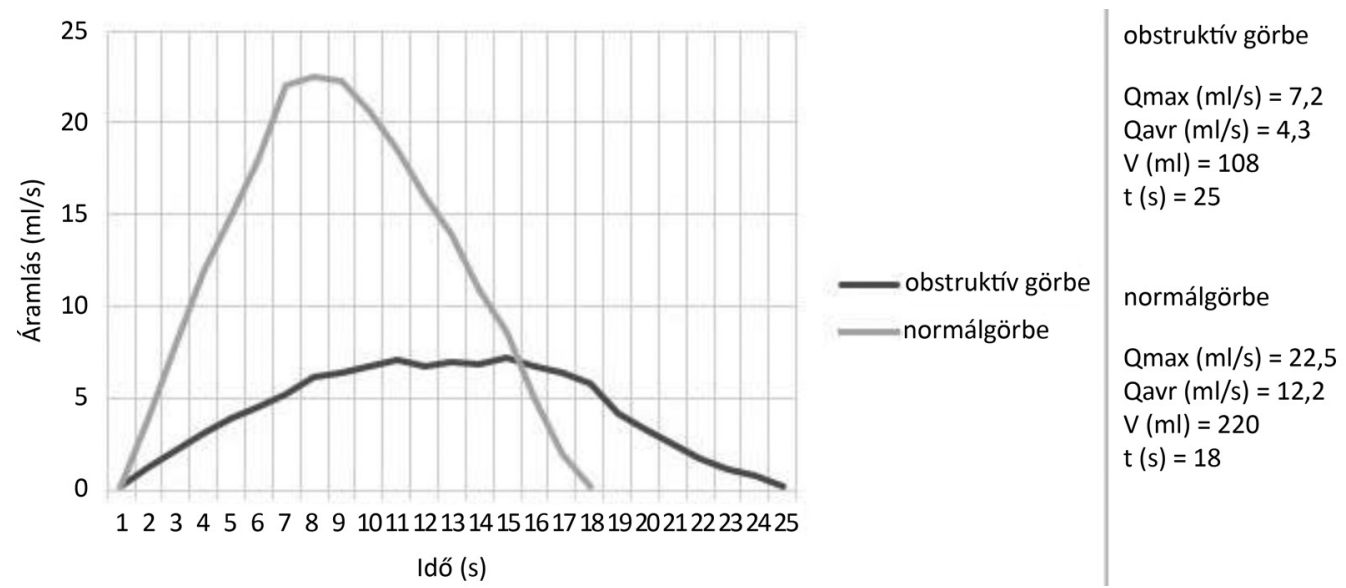

2. ábra

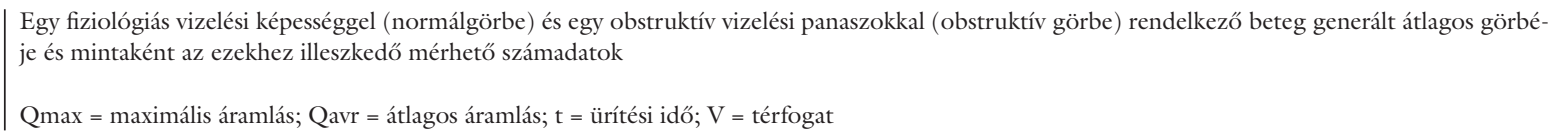

okozta a hibát, a csökkent ürített térfogat hátterében nagy valószínűséggel a beszúkült hólyagkapacitás vagy vizeletretenció állhatott. Kevés panasz, enyhe-mérsékelt tünetek és 15 alatti IPSS-pont esetén a vizsgálatot megismételtük. Amennyiben a beteg az ismétlésbe nem egyezett bele, vagy valamilyen okból nem valósult meg a hibás eredmény újramérése, úgy azt a beteget a vizsgálatból kizártuk (meglévő egyéb eredményei sem kerültek felhasználásra).

A hólyagban maradt vizelet mennyiségét suprapubicus ultrahangvizsgálattal mértük. Közvetlenül az uroflow vizsgálat (hólyagürítés) után megmértük a hólyag átmérőit. Ezután egy speciális, elnyújtott elliptoid formula szerint számolva megkaptuk a hólyagban maradt vizelet térfogatát (3. ábra), a következő képlet

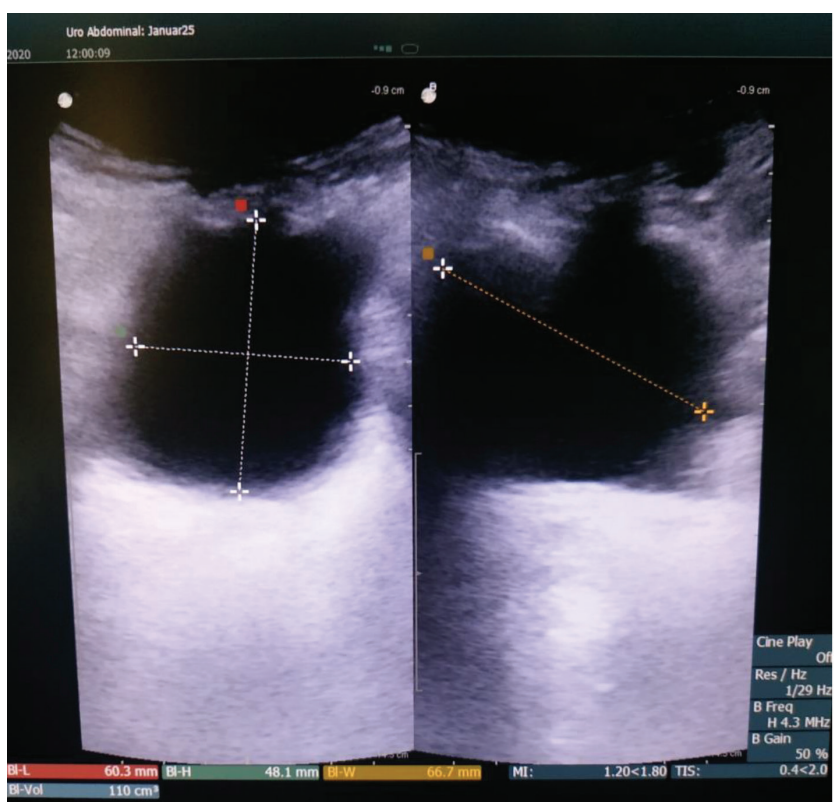

3. ábra

Ultrahang segítségével suprapubicusan mérhető hólyagátmérők, melyekből az elnyújtott elliptoid formula segítségével számítható a hólyagtérfogat [13] segítségével: $\mathrm{V}(\mathrm{ml})=$ mélység $(\mathrm{cm}) \times$ szélesség $(\mathrm{cm}) \times$ magasság $(\mathrm{cm}) \times 0,52$ [13]. Vizsgálatunk során az ultrahang által automatikusan számított hólyagvolumen-értéket nem vettük figyelembe, hiszen a vizsgálati protokollba a fent látható számítási metódust választottuk standardnak.

A vizsgálat kiértékelésében az 1 ábra szerinti számadatokat vettük figyelembe. Az IPSS-pontszám szerint

1. táblázat | A vizsgált két betegcsoport (BTCS, TTCS) paramétereinek átlaga a kezelés előtt és a vizsgált paraméterek Mann-Whitney U-teszttel kapott p-értékei

\begin{tabular}{|c|c|c|c|c|}
\hline \multicolumn{2}{|c|}{$\begin{array}{l}\text { A kezelés típusa / a kezelés előtt } \\
\text { vizsgált paraméterek }\end{array}$} & \multirow{2}{*}{$\begin{array}{l}\begin{array}{l}\text { BTCS } \\
(\mathrm{n}=11)\end{array} \\
65,8\end{array}$} & \multirow{2}{*}{$\begin{array}{l}\text { TTCS } \\
(\mathrm{n}=15) \\
73,3\end{array}$} & \multirow{2}{*}{$\begin{array}{l}\text { p-érték } \\
<0,001\end{array}$} \\
\hline Életkor (év) & Átlag & & & \\
\hline & Szórás & 4,7 & 4,2 & \\
\hline & Min.-max. & $56-70$ & $64-81$ & \\
\hline \multicolumn{2}{|c|}{ IPSS obst. (pont) } & 3,9 & 4,1 & 1 \\
\hline \multicolumn{2}{|c|}{ IPSS irr. (pont) } & 3,7 & 5,3 & 0,259 \\
\hline \multicolumn{2}{|l|}{$\mathrm{Qmax}(\mathrm{ml} / \mathrm{s})$} & 22,4 & 13,9 & 0,026 \\
\hline \multicolumn{2}{|l|}{ Qavr $(\mathrm{ml} / \mathrm{s})$} & 10,5 & 7 & 0,033 \\
\hline \multicolumn{2}{|l|}{$\operatorname{PVR}(\mathrm{ml})$} & 48,9 & 30,1 & 0,694 \\
\hline \multicolumn{2}{|l|}{ iPSA $(\mathrm{ng} / \mathrm{ml})$} & 9,8 & 12,8 & 0,194 \\
\hline \multicolumn{2}{|l|}{ GSC (pont) } & 6,4 & 7,1 & 0,066 \\
\hline \multirow[t]{3}{*}{ T-stádium } & Tl (fö) & $2(18,2 \%)$ & $4(26,7 \%)$ & \\
\hline & T2 (fö) & $9(81,8 \%)$ & $10(66,7 \%)$ & \\
\hline & T3 (fö) & $0(0 \%)$ & $1(6,7 \%)$ & \\
\hline \multicolumn{2}{|c|}{ Gyógyszeres kezelés (fö) } & $2(18,2 \%)$ & $5(33,4 \%)$ & \\
\hline \multicolumn{2}{|c|}{ Hormonterápia (fó) } & $6(54,5 \%)$ & $12(80 \%)$ & \\
\hline
\end{tabular}

BTCS $=$ brachytherapiás csoport GSC = Gleason - score $;$ iPSA = kiindulási prosztataspecifikus antigén; IPSS irr. = a nemzetközi prosztatatünet-értékelő lap irritatív panaszokat értékelő kérdései; IPSS obst. = a nemzetközi prosztatatünet-értékelő lap obstruktív panaszokat értékelő kérdései; PVR = vizelés után a hólyagban maradt vizelet térfogata; Qavr = átlagos áramlás; $\mathrm{Qmax}=$ maximális áramlás; TTCS = teleterápiás csoport 
0-14 pont esetén enyhe-mérsékelt, e felett súlyos vizelési nehezítettségról beszélünk. Az uroflow vizsgálat során a Qmax esetén $15 \mathrm{ml} / \mathrm{s}$, a Qavr esetén $5 \mathrm{ml} / \mathrm{s}$, az ürített volumen esetén pedig $150 \mathrm{ml} / \mathrm{s}$ értéken határoztuk meg a kóros és a fiziológiás közti határt. Az ultrahangvizsgálat esetében az $50 \mathrm{ml}$ alatti eredményt megfelelő hólyagürülésnek tekintjük, az $50 \mathrm{ml}$ felettit pedig kóros mértékú residuumnak.

A kezelések hasonlósága miatt az LDR- és a HDRcsoportot együttesen brachytherapiás csoportként (BTCS), a CK- és a LINAC-csoportot teleterápiás csoportként (TTCS) vizsgáltuk. Statisztikailag szignifikáns eltérést a p<0,05 esetekre használtunk.

\section{Eredmények}

A 1. táblázatban láthatók a két vizsgált betegcsoport kezelés előtti paraméterei, melyekből látható, hogy a TTCS-ban a betegek idősebbek voltak $(p<0,001)$, ugyanakkor kisebb volt a kezelés elötti $\mathrm{Qmax}(\mathrm{p}=$ 0,026), Qavr ( $\mathrm{p}=0,033)$, mint a BTCS-ban, jelezve a teleterápiás betegek kezelés előtti gyengébb vizelési képességét. (A statisztika készítéséhez a StatSoft Statistica programját [StatSoft Inc., Tulsa, OK, Amerikai Egyesült Államok] használtuk, a kezelés előtti paramétereket Mann-Whitney U-teszt segítségével vetettük össze) (1. táblázat).

A csoportok kiindulási paramétereinek összevetésén túl meghatároztuk az egyes csoportok paramétereiben bekövetkező változásokat is, melynek során azt találtuk, hogy a BTCS-ban a kezelés után rosszabb volt az IPSS az irritatív panaszok $(\mathrm{p}=0,003)$ és az obstruktív panaszok $(\mathrm{p}=0,011)$ tekintetében, továbbá a $\mathrm{Qmax}(\mathrm{p}=$ $0,003)$ és a Qavr $(\mathrm{p}=0,006)$ paraméter, mint a kezelés előtt, és közel $10 \mathrm{ml}$-rel nőtt a residualis vizelet mennyisége is (2. táblázat). (A statisztikai számítást a Statsoft Statistica programjával végeztük, párosított Wilcoxonpróba segítségével.)

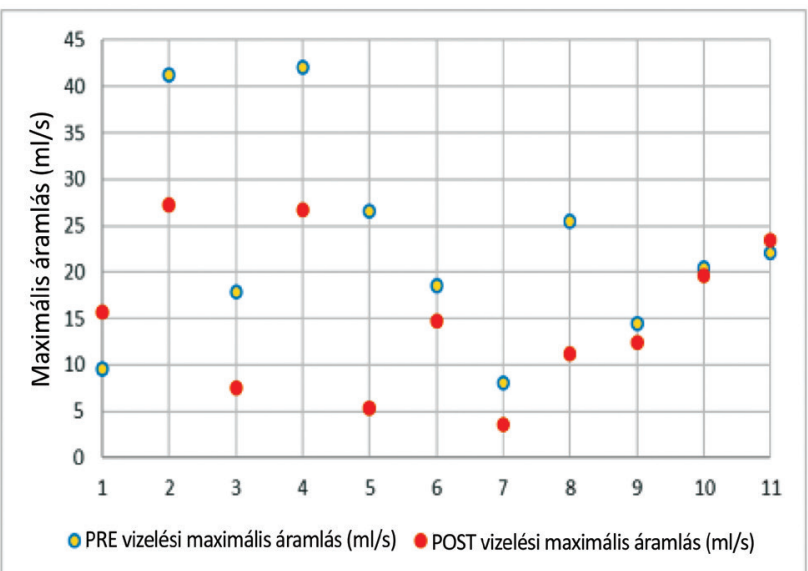

2. táblázat | A vizsgált paramétereknek az átlagértékei és azok változása a kezelés előtt és utána 4-6 héttel, valamint a párosított Wilcoxonpróbával kapott p-értéke

\begin{tabular}{llcccc}
\hline Csoportok & Vizsgált paraméter & $\begin{array}{c}\text { Átlag } \\
\text { előtte }\end{array}$ & $\begin{array}{c}\text { Átlag } \\
\text { utána }\end{array}$ & $\Delta$ & p-érték \\
\hline BTCS & IPPS obst. (pont) & 3,9 & 7,4 & 3,5 & 0,011 \\
& IPSS irr. (pont) & 3,7 & 7,3 & 3,6 & 0,003 \\
& Qmax (ml/s) & 22,4 & 15,2 & $-7,2$ & 0,003 \\
& Qavr (ml/s) & 10,5 & 7,2 & $-3,3$ & 0,006 \\
& PVR (ml) & 48,9 & 58 & 9,1 & 0,284 \\
\hline TTCS & IPPS obst. (pont) & 4,1 & 4,3 & 0,2 & 0,582 \\
& IPSS irr. (pont) & 5,3 & 7,8 & 2,5 & 0,011 \\
& Qmax (ml/s) & 13,9 & 13,5 & $-0,4$ & 0,955 \\
& Qavr (ml/s) & 7 & 7 & 0 & 0,975 \\
& PVR (ml) & 30,1 & 19,1 & -11 & 0,507 \\
\hline
\end{tabular}

BTCS $=$ brachytherapiás csoport; IPSS irr. = a nemzetközi prosztatatünet-értékelő lap irritatív panaszokat értékelő kérdései; IPSS obst. = a nemzetközi prosztatatünet-értékelő lap obstruktív panaszokat értékelő kérdései; PVR = vizelés után a hólyagban maradt vizelet térfogata; Qavr = átlagos áramlás; $\mathrm{Qmax}=$ maximális áramlás; TTCS = teleterápiás csoport

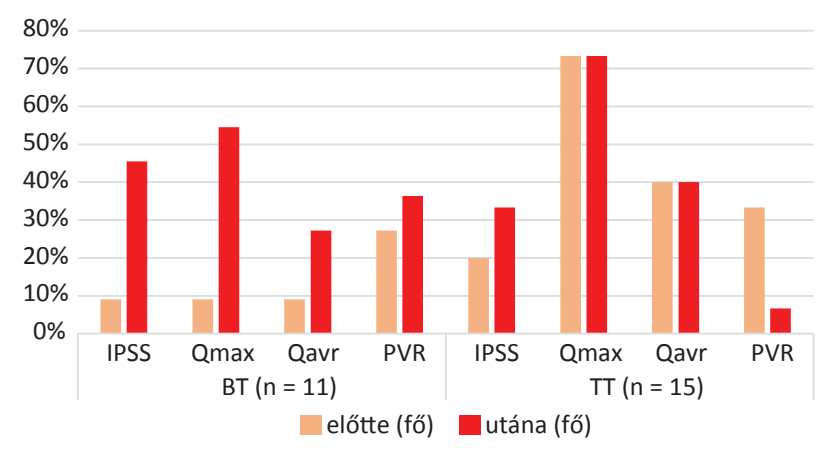

4. ábra A károsodott vizelési képességet jelző tartományokba eső bete gek arányának alakulása a vizsgálat előtt, illetve 4-6 héttel utána

$\mathrm{BT}=$ brachytherapia; IPSS = nemzetközi prosztatatünet-értékelő lap; PVR = vizelés után a hólyagban maradt vizelet térfogata; Qavr = átlagos áramlás; Qmax = maximális áramlás; TT = teleterápia

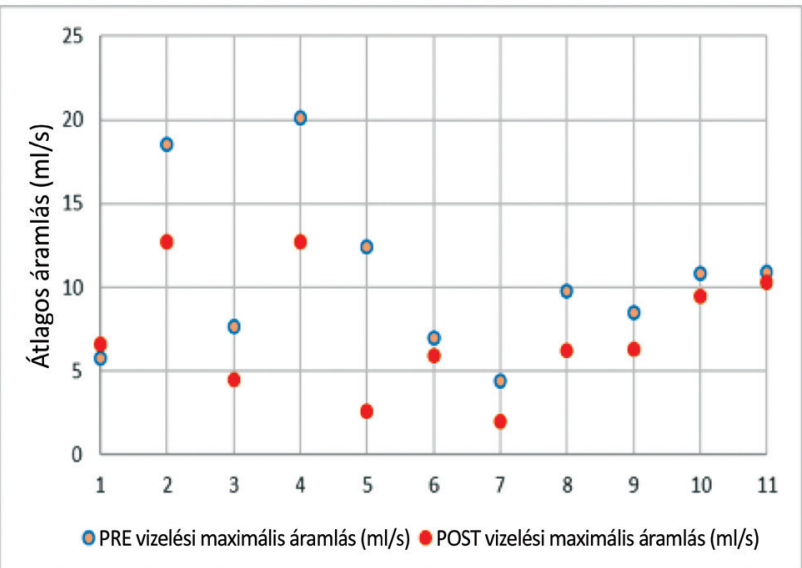

5. ábra $\quad$ A BTCS egyes tagjainak uroflowmetriával mért maximális áramlási (bal oldal) és átlagos áramlási (jobb oldal) értékei a kezelés előtt (PRE) és 4-6 héttel utána (POST)

BTCS $=$ brachytherapiás csoport 
Összevetésre került továbbá, hogy a két csoportban a különböző vizsgált paraméterek 1 . ábra szerint kóros tartományba eső értékeinek aránya hogyan alakult a kezelés előtt és után 4-6 héttel (4. ábra).

Feltüntettük a BTCS egyes tagjainak uroflowmetriával mért pontos adatait, bizonyítván, hogy a fent jelzett eltérés az egyes betegekre lebontott számadatok esetében is érzékelhető különbségeket mutat (5. ábra).

\section{Megbeszélés}

A vizsgálat elvégzésére azért került sor, mert kevés olyan tudományos közlemény áll jelenleg rendelkezésre, amely kifejezetten a sugárterápiás módszerek mellékhatásait kívánja összehasonlítani objektív módszerekkel. Elvétve vizsgálják hasonló betegcsoportok esetében uroflow készülékkel a vizelési képességet [14], annak ellenére, hogy ez a módszer költséghatékony, és minimális megterhelést jelent mind a beteg, mind a vizsgáló szemszögéből.

Kíváncsiak voltunk arra is, hogy mennyire képes ez a könnyen elvégezhető, megfelelő előkészítéssel gyorsan végrehajtható vizsgálat leírni a vizelési képesség romlását. Erre a kérdésünkre a gyakorlati tapasztalattal javarészt megegyező, jól értelmezhető eredmények születtek. Az eddigi kezelési tapasztalatok ugyanis azt mutatják, hogy a brachytherapiás módszerek rövid távon jóval markánsabb vizelési tüneteket okoznak, mint teleterápiás alternatíváik, amit ez a vizsgálat is alátámaszt.

A végső konklúzió ennél természetesen sokkal bonyolultabb, hiszen a kapott eredményeinket befolyásolhatta, hogy a kezelés előtt a betegek komoly hányada hormonterápiában részesült, illetve hogy a vizelési képességet javító (például $\alpha \mathrm{l}$-receptor-blokkoló) gyógyszeres terápia szempontjából sem volt egységes a vizsgált betegpopuláció (1. táblázat). Megjegyzendő, hogy protokollszerüen minden, brachytherapiában részesült beteg a kezelés után a következő kontrollvizsgálatig vagy a vizelési panaszai megszűntéig NSAID típusú gyulladáscsökkentő és $\alpha$-receptor-blokkoló kezelésben részesült, míg a TTCS-ban ezek a szerek csak szükség esetén kerültek felírásra a kezelést követő kontrollvizsgálaton, mely a mérésünk után történt. Továbbá az a tény is, miszerint a két csoport életkorában különbség volt látható $(\mathrm{p}<0,001)$. Jóllehet ez inkább megerósíti az eddigi tapasztalásainkat, hiszen az életkor növekedése arányos a vizelési képesség romlásával [15], amit a kezdeti Qavr $(\mathrm{p}=0,033)$ és $\mathrm{Qmax}(\mathrm{p}=0,026)$ különbség is igazol (1. táblázat). A jelen esetben a TTCS-ban volt magasabb az átlagéletkor, és ez a csoport rendelkezett a roszszabb uroflowmetriás eredményekkel. Ez a jelenség azt is igazolja, hogy az alkalmazott kezelés megválasztásakor mérlegelésre kerül a beteg általános állapota, jelenlegi vizelési képessége, jövőbeli szexuális igénye. Ezek alapján magyarázható, hogy a valamelyest nagyobb megterhelést jelentő brachytherapia inkább fiatalabb betegek esetében kerül elvégzésre, míg a teleterápia az idősebb, gyengébb általános állapotú betegek esetében gyakrabban választott alternatíva.

Megjegyzendő, hogy szignifikáns romlás leginkább a BTCS-ban volt megfigyelhető, pedig ez a betegcsoport volt az, amelyben a kezelés után protokollszerúen minden beteg részesült a fent említett, vizelési képességet javító gyógyszeres terápiában, így ez még inkább hangsúlyossá teszi a brachytherapia akut mellékhatásait és a különbséget a teleterápiához képest.

Látható, hogy a BTCS-ban a kezelés után a kiinduló helyzethez képest jóval több esetben regisztráltunk kóros vizelési értékeket, ez viszont arányaiban még mindig kevesebb, mint a TTCS esetében (4. ábra). Ennek tükrében meglepő eredmény, hogy a TTCS esetében mindössze az IPSS-nek az irritatív panaszokat leíró értéke ( $\mathrm{p}=$ 0,011) lett szignifikánsan rosszabb a 4-6. heti mérésen.

Az 1. táblázatban látható, uroflowmetriával mért adatok közötti eltérés bizonyítja, hogy a kezelés típusának megválasztásában szerepe van a vizelési képességnek, illetve az IPSS-nek, ami valamennyire helyesen segít elkülöníteni a brachytherapiás és a teleterápiás kezelésben részesülő betegeket. Ugyanakkor az uroflowmetria is könnyen elvégezhető, és akár egy pontosított pontrendszer segítségével megbízhatóbban segíthet a megfelelő kezelés megválasztásában és a betegek kezelés előtti szûrésében.

Bár bizonyítottuk, hogy a vizelési minőséget - mind az IPSS-teszt alapján, mind az uroflow vizsgálat számadatai alapján - a kezelés utáni korai (akut) szakban jelentősebben befolyásolja a brachytherapia, mint a teleterápia, az alacsony betegszám miatt további vizsgálatokra van szükség.

A vizsgálat értéke, hogy az első munka, amelyben a CK készüléken kezelt betegek esetében uroflow vizsgálattal mérik a vizelési minőség változásait a korai posztterápiás szakaszban. Előnye továbbá, hogy egy intézetben, egy munkacsoportban, jól meghatározott protokoll alapján történt minden kezelés és vizsgálat, és ez lehetőséget adott arra, hogy a különböző terápiás modalitásokat össze tudjuk vetni egymással.

A vizsgálat kiterjesztésének szükségességét az a tény is felveti, hogy a jelen dolgozatban mindösszesen az akut mellékhatásokat tudtuk vizsgálni, azon belül is a terápia utáni igen korai, kb. 1 hónapos fázist. Ebben az időszakban - mint ahogy bizonyítottuk - az összes terápiás modalitás tekintetében még inkább az irritatív panaszok kerülnek előtérbe. Nyitott kérdés, hogy hogyan alakul a továbbiakban a kezelés után, hosszabb követés során (késői fázis) a vizelési képesség.

Célunkat, hogy az uroflow vizsgálat eredményét az alkalmazandó sugárkezelés típusának kiválasztásához figyelembe ajánljuk, illetve felhívjuk a figyelmet arra, hogy jelentős különbség van a vizelési képesség romlásában a különböző modalitások között (az akut mellékhatások esetében), teljesítettük. 


\section{Következtetés}

Elmondható, hogy a szervre lokalizált prosztatarák besugárzásában alkalmazott módszerek között a brachytherapiát kapó betegek esetében az uroflow paraméterek (Qmax, Qavr) korai romlása nagyobb mértékú, mint a teleterápiával kezeltek körében. Ezért megfontolandónak tartjuk a terápiás modalitás kiválasztásakor az uroflow vizsgálat elvégzését. A középsúlyos vagy súlyos dysuriás vizelési panaszokban szenvedóknél brachytherapia helyett a teleterápiás módszereket javasoljuk, amelyek kevésbé rontják a beteg vizeletürítési képességét. A sugárkezelés okozta késői mellékhatások felméréséhez a betegszám növelését és a betegek hosszabb követését tervezzük.

Anyagi támogatás: A kutatás és a közlemény megírása anyagi támogatásban nem részesült.

Szerzői munkamegosztás: N. I.: A vizsgálatok elvégzése, irodalomkutatás, adatgyújtés, a kézirat összeállítása, az ábrák és a táblázatok elkészítése. M. S., Sz. J. F.: A munkacsoport tagjai. Részt vettek a betegvizsgálatban, illetve a kézirat szakmai véleményezésében. F. G.: Statisztikai számítások végzése. P. Cs.: Részt vett a kézirat szakmai véleményezésében. Á. P.: Témavezetőként irányította a kutatást, és részt vett a kézirat végső formájának kialakításában. A cikk végleges változatát valamennyi szerző elolvasta és jóváhagyta.

Érdekeltségek: A szerzőknek nincsenek érdekeltségeik.

\section{Irodalom}

[1] Jemal A, Bray F, Center MM, et al. Global cancer statistics. CA Cancer J Clin. 2011; 61: 69-90.

[2] Kásler M, Ottó Sz, Kenessey I. The current situation of cancer morbidity and mortality in the light of the National Cancer Registry, Hungary. [A rákmorbiditás és -mortalitás jelenlegi helyzete a Nemzeti Rákregiszter tükrében.] Orv Hetil. 2017; 158: 8489. [Hungarian]

[3] Siegel LR, Miller DK, Jemal A, et al. Cancer statistics. CA Cancer J Clin. 2016; 66: 7-30.
[4] Mottet N, Bellmunt J, Bolla M, et al. EAU-ESTRO-SIOG Guidelines on prostate cancer. Part 1. Screening, diagnosis, and local treatment with curative intent. Eur Urol. 2017; 71: 618629.

[5] Zaorsky NG, Ohri N, Showalter NT, et al. Systematic review of hypofractionated radiation therapy for prostate cancer. Cancer Treat Rev. 2013; 39: 728-736.

[6] Meier RM, Bloch DA, Cotrutz C, et al. Multicenter trial of stereotactic body radiation therapy for low- and intermediate-risk prostate cancer: survival and toxicity endpoints. Int J Radiat Oncol Biol Phys. 2018; 102: 296-303.

[7] Ash D, Flynn A, Battermann J, et al. ESTRO/EAU/EORTC recommendations on permanent seed implantation for localized prostate cancer. Radiother Oncol. 2000; 57: 315-321.

[8] Sanda MG, Dunn LR, Michalski J, et al. Quality of life and satisfaction with outcome among prostate-cancer survivors. N Eng J Med. 2008; 358: 1250-1261.

[9] Crook MJ, Gomez-Iturriaga A, Wallace K, et al. Comparison of health-related quality of life 5 years after SPIRIT: surgical prostatectomy versus interstitial radiation intervention trial. J Clin Oncol. 2011; 29: 362-368.

[10] Grimm P, Billiet I, Bostwick D, et al. Comparative analysis of prostate-specific antigen free survival outcomes for patients with low, intermediate and high risk prostate cancer treatment by radical therapy. Results from the Prostate Cancer Results Study Group. BJU Int. 2012; 109(Suppl 1): 22-29.

[11] Matta R, Chapple CR, Fisch M, et al. Pelvic complications after prostate cancer radiation therapy and their management: an international collaborative narrative review. Eur Urol. 2019; 75: 464-476.

[12] Ohri N, Dicker AP, Showalter TN. Late toxicity rates following definitive radiotherapy for prostate cancer. Can J Urol. 2012; 19: 6373-6380.

[13] Malu I. The prognostic value of post-void residual urine volume, abdominal prostate and transrectal prostate ultrasound for complication of benign prostate hyperplasia: a case report sonographic analysis. Int J Radiol Radiat Oncol. 2019; 5(1): 001008. Doi: http://dx.doi.org/10.17352/ijrro.000032.

[14] Martens C, Pond G, Webster D, et al. Relationship of the international prostate symptom score with urinary flow studies, and catheterization rates following 125I prostate brachytherapy. Brachytherapy 2006; 5: 9-13.

[15] Jørgensen JB, Jensen KM, Bille-Brache NE, et al. Uroflowmetry in asymptomatic elderly males. Br J Urol. 1986; 58: 390-395.

(Ágoston Péter dr., Budapest, Ráth György u. 7-9., 1122 e-mail: peter.agoston@yahoo.com)

A cikk a Creative Commons Attribution 4.0 International License (https://creativecommons.org/licenses/by/4.0/) feltételei szerint publikált Open Access közlemény, melynek szellemében a cikk bármilyen médiumban szabadon felhasználható, megosztható és újraközölhető, feltéve, hogy az eredeti szerző és a közlés helye, illetve a CC License linkje és az esetlegesen végrehajtott módosítások feltüntetésre kerülnek. (SID_1) 